\title{
nature
}

\author{
30 April 1981
}

\section{New guard at the National Academy}

The annual meeting of the National Academy of Sciences in Washington this week is something of a milestone. Among other things, the scientific programme includes a meeting to mark the impending retirement of Dr Philip Handler as president of the academy. From then until 1 July, when Dr Frank Press takes over, he will be something of a lame duck, which does not mean that he will be less outspoken than in the past. (President Eisenhower, one of the most taciturn and even inarticulate of presidents, waited until his lame-duck period before making his unexpected but still memorable attack on the "military-industrial complex".) Inevitably, however, the academy's army of committee members will from now on be guessing at the changes that Press's succession is likely to bring. Handler will have to try harder if he seeks to capture their attention.

He should not feel slighted. Handler has done a distinguished job in his two six-year stints as president of the academy. Neither of his immediate predecessors could have done as well. Dr Detlev W. Bronk's apparently randomly directed ebullience may have suited the spirit of the late fifties and early sixties, but would have landed him perpetually in hot water in the past decade. Similarly, Dr Frederick W. Seitz's masterly passivity, well suited to the booming budgets of the mid-sixties (but wearing thin towards the end) would have led him into trouble in the turbulent seventies. Handler's spell at the academy has been a much rougher ride. During this period, budgets have been falling, Congress has assumed much more explicitly than before the role of public watchdog over - some would say public prosecutor of - the scientific enterprise, which has also been threatened by the environmental nonsenses of the early 1970s and the fuss about genetic manipulation at the end of the decade. Inevitably, Handler has frequently been forced to play defending counsel. To his credit, he has done this job courageously - and in the process has made some stirring speeches.

Unlike the scientific academies of Western Europe, the United States academy has the seeds of dissension built into its constitution. Thus it resembles the academies of Eastern Europe in having a formal relationship with Congress, which is empowered to commission studies on whatever questions happen to flit across the scene. If, for example, Congress wishes to know whether small doses of radiation are dangerous, whether the accumulation of chlorofluorohydrocarbons in the atmosphere will dangerously deplete the ozone layer or whether the Department of Energy is telling the truth about energy forecasts, many committees of Congress will think first of commissioning a study from the academy. Technically, the work is done by the National Research Council, in whose management both the academies of engineering and medicine have a part, but in the public mind (and that of Congress) the academy of sciences is responsible. Since by definition the subjects on which Congress asks for advice are contentious, the academy frequently finds itself at the centre of public argument. Last year's report on the effects of small doses of radiation (see Nature 286, 550; 1980) was a good illustration of the troubles that can arise. Occasionally, the academy asks for trouble, as with its own committee's pungent advice that people should not be unduly concerned with the exact composition of what they eat (see Nature 285, 428; 1980). One of Handler's tasks, in the past twelve years, has been to give this stream of documents a collective stamp of authority. For the future, it would be better if the academy could arrange to shuffle off commissions for studies which are either pointless or untimely. Too much of what it has attempted should have been refused, and should be in the future.

That is one task for Dr Frank Press. Another is to redefine the ground on which the scientific enterprise is defended. Hitherto, the academy's machinery for cogitating about problems of general concern has been directed towards specific contemporary problems, where data gathered by research promise to illuminate matters of general interest. The academy has been much less concerned with the machinery by which the scientific enterprise is sustained. The education of students in schools and colleges? The National Science Foundation has been allowed to set the pace, at least until its budget was slashed last month. The problem of university scientists, with or without tenure, engaged in the increasingly hazardous gamble of the pursuit of scholarship? Leave that to the American Council on Higher Education, which has strong opinions on issues such as tenure - and hope that people will one day recover from the over-abundance of documents churned out by the Kerr commission on higher education. The propriety of the arrangements academics make with their universities to share in the profits of extramural commercial enterprises? Or that universities make with commercial companies or with agencies of the federal government? The universities, the argument seems to go, are too jealous of their independence to welcome advice.

As events have turned out, the academy in Washinton should move quickly to take up these and a host of related questions. Although the competitive universities and colleges of the United States are rightly proud of their autonomy, they are now afflicted by so many common and pressing problems that the academy's influence could be decisive. Should the protest against the new strict interpretation of the rules prohibiting the export of military material, which threatens to restrict the education of overseas graduate students, be left to a handful of college presidents (see Nature 9 April)? Are the new rules introduced by the Office of Manpower and Budget for accounting for the use of federal funds equitable or merely iniquitous? And will they achieve their declared purpose of saving federal dollars? Is it sensible that sources of financial support for graduate students should be as much curtailed as in the past few years? What - in the national interest as well as that of research - should be the balance in the funding of research between project grants (with their accompanying variable overhead percentages) and straight institutional support (of which there is at present almost none)? And if institutional support comes back into fashion, to which institutions should it be channelled by which agencies? Many of these are tedious questions, but they are much more important than the consequences of aerosols in the atmosphere.

The surprise so far is that the academy seems to have had very little interest in these issues. They are of course intangible and often boring. There is also always the danger that if a body such as the National Academy of Sciences speaks out forthrightly on these subjects, it will be accused of self-serving propaganda on behalf of its members. That risk is worth running. Indeed, the risk must be run. For with so many other well-wishers of the scientific enterprise emasculated by President Reagan's first budget, the academy is almost the only institution in Washington able to speak out. Moreover, the issues are likely to induce a harmony of purpose among the members of the academy sufficiently strong to carry the institution through the divisive issues certain to crop up in the next six years as in the past twelve - whether, for example, to protest at Sakharov's exile and, if so, how? Is this an agenda for Dr Frank Press? 